Special Issue on Migration and Globalization, Canadian Studies in Population

Vol. 29(1), 2002, pp. 31-52

\title{
Globalization, Migration and Development
}

\author{
John Samuel \\ Susan George \\ Carleton University \\ Ottawa, Ontario, Canada
}

\begin{abstract}
Migration may become the most important branch of demography in the early decades of the new millennium in a rapidly globalizing world. This paper discusses the causes, costs and benefits of international migration to countries of the South and North, and key issues of common concern. International migration is as old as national boundaries, though its nature, volume, direction, causes and consequences have changed. The causes of migration are rooted in the rate of population growth and the proportion of youth in the population, their education and training, employment opportunities, income differentials in society, communication and transportation facilities, political freedom and human rights and level of urbanization. Migration benefits the South through remittances of migrants, improves the economic welfare of the population (particularly women) of South countries generally, increases investment, and leads to structural changes in the economy. However, emigration from the South has costs too, be they social or caused by factors such as brain drain. The North also benefits by migration through enhancement of economic growth, development of natural resources, improved employment prospects, social development and through exposure to immigrants' new cultures and lifestyles. Migration also has costs to the North such as of immigrant integration, a certain amount of destabilization of the economy, illegal immigration, and social problems of discrimination and exploitation. Issues common to both North and South include impact on private investment, trade, international cooperation, and sustainable development. Both North and South face a dilemma in seeking an appropriate balance between importing South's labour or its products and exporting capital and technology from the North.
\end{abstract}

Key Words: International migration, migration costs and benefits, causes of migration 
John Samuel and Susan George

\section{Résumé:}

Migration may become the most important branch of demography in the early decades of the new millennium in a rapidly globalizing world. This paper discusses the causes, costs and benefits of international migration to countries of the South and North, and key issues of common concern. International migration is as old as national boundaries, though its nature, volume, direction, causes and consequences have changed. The causes of migration are rooted in the rate of population growth and the proportion of youth in the population, their education and training, employment opportunities, income differentials in society, communication and transportation facilities, political freedom and human rights and level of urbanization. Migration benefits the South through remittances of migrants, improves the economic welfare of the population (particularly women) of South countries generally, increases investment, and leads to structural changes in the economy. However, emigration from the South has costs too, be they social or caused by factors such as brain drain. The North also benefits by migration through enhancement of economic growth, development of natural resources, improved employment prospects, social development and through exposure to immigrants' new cultures and lifestyles. Migration also has costs to the North such as of immigrant integration, a certain amount of destabilization of the economy, illegal immigration, and social problems of discrimination and exploitation. Issues common to both North and South include impact on private investment, trade, international cooperation, and sustainable development. Both North and South face a dilemma in seeking an appropriate balance between importing South's labour.

Key Words: International migration, migration costs and benefits, causes of migration

\section{Introduction}

Homo sapiens have seldom been sedentary. From a global perspective, currently about 125 million persons form the pool of international migrants (Gelbard, Haub and Kent, 1999: 15). Migration has the potential to become the most important branch of demography in the early decades of this millennium. This paper discusses the causes of migration in a globalizing world, its costs and benefits to the South and the North countries, and some key issues common to both the South and North. The core of this paper is an exploration into the way in which development and migration influence each other within the global context. 
Globalization, Migration and Development

\section{Definitions}

The term migration is defined broadly as a permanent or semi-permanent change of residence. It includes permanent settlers or landed immigrants, temporary workers, guest workers, asylum seekers, students, and undocumented arrivals with the intention of short- or long-term settlement. Tourists and similar shortterm visitors, and the diplomatic community are excluded from this definition.

The definition of the term development is more complex. It is defined as a "process of improving quality of all human lives, and it entails three important aspects that are: raising peoples living levels; creating conditions conducive to the establishment of social, political and economic systems and institutions that promote human dignity and respect; and increasing people's freedom to choose by enlarging the range of their choice variables" (Todardo, as quoted by Samuel, 1997:3).

The term economic development is defined as "the application of capital to raise human productivity, generate wealth and increase national income. It is part of a constellation of social and cultural changes that scholars generally call 'modernization'" (Massey, 1988: 383).

The term globalization is not yet properly defined. However, a working definition of globalization could be that it is a process of rapid economic integration at a global level that is coincident with a unique pattern of sociopolitical effects transcending national boundaries.

\section{Features of International Migration}

Some of the distinguishing features of international migration in the last few decades have been as follows: First, the migration flows mainly occur from developing to developed countries. Second, a higher proportion of migrants are better qualified than the native born population in most of the countries receiving immigrants, if undocumented immigrants are excluded. Third, undocumented immigration has become a significant component of international migration despite measures adopted to prevent or reduce such migration. Fourth, females constitute an increasing proportion of international migrants; some countries (such as Canada) referring to the "feminization of migration". Fifth, the diaspora of foreign-origin persons in many countries has reached significant proportions and they have built up a certain amount of political clout.

The flow of migrants has not always been only from the poorer to richer countries. For example, annually, 238,000 Americans, despite their high standard of living, emigrated annually in the eighties and in 1988, 2 million Americans lived in other countries (Bratsberg, 1996: 789). This is partly due to 
John Samuel and Susan George

better weather conditions in some countries and the fact that a given amount of dollars goes a lot farther in developing countries such as Mexico than in the US itself. Globalization and liberalization of opportunities in the newly developing countries in Asia have also stimulated migration from the developed regions to these countries to some extent (Iredale, 2000:882).

\section{The Causes of Migration}

The causes of migration are rooted in demographic, economic, sociological, political and other factors connected to the modern development process across the globe.

\section{Population Growth and Youth}

The rate of population growth and the proportion of youth in the population influences both international migration and development. Falling mortality and high fertility maintain a high rate of population growth that, in many countries, often throws into disarray the very delicate balance between population and resources in the short run while the rising revolution of expectations gallops ahead, fuelled by education and better awareness of living conditions in the North with a helping hand from globalization.

According to Demeny, between the mid 1980s and the end of the century, the 20-40 age group, which supplies most of the economic migrants, will increase by 19 million in the North - less than a third of that of the 20 preceding years (as quoted by Swami, 1984:27). In the next two decades, according to the ILO (International Labour Office), the labor force of the developed world will grow by $40 \%$. This would mean 700 million new job seekers added to the labor force of 2.4 billion (as quoted by OECD, 1993:5). This is when the youth unemployment rate in certain countries of the South is already up to $40 \%$.

\section{Education and Training}

Education holds the key to development as well as to international migration. The U.S. Commission for the Study of International Migration and Co-operative Economic Development observes: "Raising educational levels is essential to socio-economic development and reduction of migratory pressures. An educated population is key to raising productivity. Increasing education is correlated to declining fertility and improved nutritional standards" (U.S. Commission for the Study of International Migration and Co-operative Economic Development, 1990: xxx.) While one could agree with most of the assertions above, it is doubtful whether one could claim that higher educational levels reduce migratory pressures in the short run. The evidence is largely to the contrary. For 
instance, the state of Kerala in India with the highest literacy rate of $70.4 \%$ for the population of 15 and over, has a high migration rate as well (United Nations, 1992: 15).

\section{Employment}

Many countries of the South are plagued with the problem of chronic unemployment. A dominant factor that causes migration is the job market. Lack of employment, poor wages and no prospects of advancement motivate labor force participants to seek opportunities elsewhere. In this era of economic globalization and liberalization, internationalization of firms attract skilled migrants from the South in the direction of investments, with the promise of satisfactory employment (Iredale, 2000:885).

To create employment for its growing population, some countries of the South have initiated specific programs. There are a few developing countries with free trade zones and foreign manufacturing facilities for export. Mexico has "maquiladora" (assembly) operations for foreign companies that earned U.S. \$3 billion in foreign exchange in the year 1989 and employ $15 \%$ of those who work in manufacturing jobs (U.S. Commission for the Study of International Migration and Co-operative Economic Development, 1990: xxIV). However, the employment created is inadequate when compared to the needs of the population.

\section{Income}

Income differentials between sending and receiving countries have been a major cause of international migration. According to the World Bank, in 1965, the ratio between the per capita income of low-income countries and developed countries was 1:64; in 1990, the ratio declined to 1:56 (as quoted by UNCTAD, 1993:5). The difference between 1965 and 1990 has been marginal, though in the right direction.

In the long run, when the standard of living is raised through economic development, the urge to migrate in large numbers dwindles. In the short run, however, the opposite could happen. The U.S. Commission for the Study of International Migration and Cooperative Economic Development reported in 1990, that expanded trade between the U.S. and the migrant sending countries, while enhancing economic development, could stimulate migration in the short and medium term (Martin and Midgley, 1999: 13). Only more research can identify the threshold at which the urge to migrate disappears. Martin reports that the experience with Italy and the other southern European entrants into the EC suggests that only a decade is required to reduce wage gaps from seven to one to four to one, and that faster wage and job growth at home than abroad is 
John Samuel and Susan George

sufficient to stop migration, despite higher wages, and the legal right to work in another country.

\section{Communication and Transportation}

The advancement of communication and transportation has influenced the process of migration and development. The print and electronic media increase awareness and provide information to access the better life opportunities in a different country. Social networks created by earlier emigrants from one's own community further facilitate such movements. Gone are the days of communicating using a confusing smoke signal on the top of a hill. The telephone, the computer, the electronic mail and the fax machine have revolutionized communication. To quote the defense expert Albert Wohlstetter, "The fax shall make you free" (as quoted in The Wall Street Journal, 1993:10).

\section{Political Freedom and Human Rights}

Political freedom and human rights protection are closely associated with migration and influences development. Pressures of population growth and no or little improvement in per capita incomes, tend to spawn political instability and trigger ethnic and religious tensions leading to human rights abuses and refugee movements. Constraints on political freedom and the prevalence of dictatorial regimes that trample on human rights have been a most important motivator for migration. "Lack of democratic rule, good governance and respect for human rights often coupled with excessive military expenditures are among the root causes for refugee movements" (OECD, 1991:16.) In 1998, the number of officially recognized refugees and asylum-seekers living outside their home countries peaked at 13.6 million. That year, 5.7 million refugees lived in the Middle East, 2.9 million in Africa and 2 million in Europe (Gelbard, Haub and Kent, 1999: 16).

Ethnic and religious issues, simmering or boiling over, have caused migration for some time. Examples include ethnic tensions in Lebanon, where $36 \%$ of the country's population was outside Lebanon in 1992, Sri Lanka (for which the percentage was nine) and former Yugoslavia, (The Economist, 1993:40) and fundamentalism in Iran and Algeria.

It is obvious that lack of political freedom and human rights violations combined with the absence of economic growth and prosperity led to the arrival of large numbers of refugee claimants in Europe and North America. According to an estimate, Western European nations spend $\$ 8$ billion annually (equivalent to one-sixth of Official Development Assistance, to sort out and deport economic refugees vis-à-vis political refugees (Martin, 1992: 1002.) In Canada, this amount was close to $\$ 1$ billion annually. 


\section{Urbanization}

Urbanization and development often go hand in hand. Urban-centered development processes encourage migration to the urban areas. Urban migration is often the initial step followed by a proportion of international migrants. Those who have moved once are likely to move again. At times, Urban movers exert pressure on existing urban dwellers to move abroad in search of better opportunities.

Urbanization is continuing at a rapid pace in many Southern countries despite overcrowding in the cities. Bombay, Cairo, Chengdu, Hong Kong, Ho Chi Min City, Jakarta, Lagos, Shanghai and Tianjin had densities in excess of 80,000 persons per square mile in the early eighties (U.S. Immigration and Naturalization Service, 1986: 28).

Providing required facilities in smaller urban centres or rural areas, with incentives to stay, would reduce the pressure to migrate to larger centres and from there to other countries. Local development programs could favor smalland medium-size cities with enhanced leisure infrastructure along with business ventures owned and operated by young people. "The existence of more attractive working and living conditions (in rural areas, small and medium towns) is a factor likely to reduce the propensity to emigrate" (Kasmi, 1993:17).

\section{The Costs and Benefits of International Migration}

At times, the difference between costs and benefits of international migration is not too well defined and what appears to be a short-term cost may turn out to be a long-term benefit. The costs and benefits of international migration for countries will be analyzed from the angle of the sending and the receiving countries.

\section{Benefits of International Migration to South Countries}

International migration is beneficial most often to both sending and receiving countries. To the sending countries, the advantages could be economic, social and to some extent political. Economically, the sending countries could reap enormous benefits such as foreign exchange remittances, investment, technology transfer and training for its labor force. Socially, the emigration to a developed country brings the cultures of the two relevant societies in greater contact, and the ideas, attitudes, policies and practices that helped to foster economic and social development in the North become more easily available and accessible to developing countries. This facilitates modernization of more traditional societies 
John Samuel and Susan George

and enables the two types of societies to understand each other better and to enrich each other culturally.

\section{Remittances}

Remittances have contributed a substantial proportion of private capital flows in recent years. In 1970, official development assistance amounted to US\$ 5.6 billion while total private flows were $\$ 5.8$ billion. By 1996 , according to preliminary numbers, while official development assistance rose to $\$ 40.8$ billion, private flows were at $\$ 243.8$ billion (Kappagoda, 1998). Developing countries received $40 \%$ of foreign direct investment flows in 1996 compared to $15 \%$ in 1990 and the share of East Asia and the Pacific was US\$ 61.1 billion with China getting the major share. The Chinese diaspora in developed countries is presumed to have a lot to do with these investment flows to that region.

Remittances of emigrants improve balance of payments of the recipient country and the living standards of emigrants and their relatives. A World Bank study on the use of remittances in Bangladesh, the Philippines, Turkey, Pakistan and India shows that "purchase of residential plots, house construction and house improvement are expenditures that receive priority" (Swamy, 1984: 44). In Turkey, Bangladesh and Pakistan substantial investments in private businesses were also reported (Ibid: 45). A study reported "considerable benefits and limited costs for the Greek economy...Remittances promote economic growth, employment and capital formation" (Glytsos, 1993: 154).

Even if all the remittances do not go immediately into investment, consumption promotes demand for goods and services and creates employment with a multiplier effect. A study from Mexico supports the generally-held view that Mexico-US migration stimulates economic activity, both directly and indirectly, and that it leads to significantly higher levels of employment, investment, and income within specific communities and the nation as a whole.

\section{Emigration and Economic Welfare}

Emigration is likely to accelerate economic growth in some countries. In certain situations mass emigration clears up redundant labor or disguised unemployment, stimulates the economy by increasing the return to efficient utilization of resources, and in particular, encourages the adoption of machinery which saves capital resources as well as labor.

Generally, emigration does not reduce population growth rate to such an extent as to promote significant economic development in developing countries. However, the converse may be true in the case of some small Caribbean countries which have benefited significantly from emigration. 
Migration leads to strong economic linkages between the sending countries and the receiving countries and leads to global economic restructuring. An instance in point is the growth of the Korean wig industry. There was a rapid growth of export-oriented wig industry in South Korea and they became a major export item helping both South Korea and Korean immigrants in the US (Chin, 1996: 485).

\section{Migration and Women}

As seen earlier, over the last many decades, the proportion of women who migrate for temporary jobs has increased consistently, along with increased levels of education in sending countries. Increased feminization occurred among Turkish workers in Germany where the proportion of women among guest workers went up from 6.9 in 1960 to 26.0 in 1975 (Abadan-Unat, 1977: 31). While the urbanization and modernization experience of these women had an emancipating impact on them, women left behind in Turkey had to assume greater economic roles since the men were away. Immigration has increased the participation of women in economic life, and their geographic and occupational mobility. It has had an important effect on the social status of women, facilitating emancipation of women and the process of modernization of their communities.

Immigration experience could also vary across gender. For instance, JonesCorrea refers to a study of Latin American immigrants indicating that women experience less downward mobility in the job market and thus suffer less internal consistency than men do (Jones-Correa, 1998: 327). He suggests that immigration experiences of men and women and the social benefits they seek out of organizational life, would lead to different political strategies in the host country (Ibid: 346 ).

\section{Return Migration and Investment}

Immigrants retain one foot in the home country and another in the host country soon after migration. As circumstances change, and as they achieve the economic objective they sought in one country or because they fail to achieve their goals, a certain number eventually returns or re-migrates.

Return migration may also occur because of non-economic factors. Migration is considered a "stressful life event" along with divorce and the death of a close relative. Often the stress is not recognized as a cost of migration until after the move and the migrant develops a certain romantic notion of life before the move. As Davidson suggested: "the glow of memory warms the heart towards the homeland, time and distance blunting the recollection of the pressures that 
John Samuel and Susan George

led to migration" (cited in Samuel, 1969: 112). A Canadian study estimated that close to a quarter of Canadian immigrants have departed after 10 years. Regarding Canadian immigrants in the US, over a third are reported to have returned to Canada (Samuel, 1969; Comay, 1971) during the same period.

A certain proportion of all international migrants, including the professionals, return home eventually to their countries of birth often enriched financially and in terms of skill. Some of the returnees start enterprises using the capital, skills and contacts they have acquired and help in the development of their country of birth. Also important are the spirit of experimentation and entrepreneurship, and the different set of social values they bring back with them. Return migration of ex-patriots is also probably the best means of technology transfer from North to South.

\section{Attention Drawn to Structural Changes}

Pressure to emigrate legally or illegally, helps to draw the attention of the powers that be on the economic problem of the country concerned. In the case of Mexico there has been inadequate growth of productive employment, distortions in income distribution and rapid population growth. The problems have been massive and long enduring.

\section{Costs of Emigration to South Countries}

The sending countries lose human resources they raised and educated to the North countries. Apart from this, such migration also relieves the political pressure on developing countries to address urgent economic issues of unemployment and underdevelopment and social issues such as care of the elderly.

\section{Social Costs}

Bohning holds the view that "migration from poor to rich countries may, however, perpetuate itself where the availability of labor retards structural change in the immigration country and in the international division of labor. Therefore, national and international policies in the field must reconcile the short-run function of poverty relief with the long-run goal of obviating the need for emigration. Put another way, the poverty relief function should demonstrably make the emigration country decreasingly dependent upon the export of labor and should increasingly enable it to employ its citizens productively at home"(1976: 152). Once abroad, migrants acquire skills and savings, that can be used productively at home without stoking inflationary tendencies. 
Emigration is considered to be an escape valve. "Emigration provides an escape for dissident and energetic elements who might otherwise provide leadership and a critical mass for change. Where would Poland be, for example, if Lech Walessa was an electrician in Chicago? How long would Fidel Castro retain control in Cuba if the opposition there stayed put?" (Abernethy, 1996: 133). However, it is hard to make such assumptions in a realistic manner and assess possible differences.

Furthermore, a study in Hong Kong shows that emigration has led to elderly parents or mentally retarded children being left alone in Hong Kong. The residence requirement for a foreign passport that separates marriage partners also contributes to the increased number of divorce cases.

\section{Brain Drain}

The term brain drain refers to the loss of skilled professionals and the non-return of students from advanced study in another country. Some claim that the brain drain is a drag on development. For instance, Wood refers to "the huge development loss represented by the 'brain drain' from the less developed to the more advanced countries" and describes it as "increasingly damaging drain" (Wood, 1993: 23). However, the OECD maintains the appropriate perspective when it says that "while in some developing countries the loss of trained people is having only a little impact on the local supply of skilled labor, in other countries the emigration of professional and skilled workers is seriously hindering basic administrative, economic and social functions -- as the current experiences of some Southern African Countries and the Central Asian republic shows" (OECD, 1993:9).

Whether any form of emigration of skilled persons is a loss to the sending country depends on the supply and demand for their skills in the same country. In anticipation of high growth rates, some developing countries make a heavy human capital investment in their labor force through education. However, the economic growth rate projected is not always achieved, and the country cannot absorb all those who were trained. This gives rise to the need for skilled professionals to migrate.

The receiving countries point out that scientific discoveries made by immigrants in one country ultimately benefit all countries. U.S demographer, Everett Lee, maintains that one third of Nobel Prize winners in the US were foreign born. It is considered unlikely that they would have been able to achieve as much in their former countries with the limited resources for scientific research.

Bohning has emphasized the importance of balancing the advantages of migration such as relief of an unemployment situation, remittances of foreign 
John Samuel and Susan George

exchange, return migrants bringing back knowledge and tools, against the disadvantages of migration.

\section{Benefits of Immigration to North Countries}

For receiving countries, immigration creates almost a win-win situation. Immigrants cause structural changes in the economy, promote economic growth, helps the utilization of natural resources and building of infrastructures such as railways, subways, and roads, creates employment opportunities, and promotes social development.

\section{Immigrants and Economic Growth}

Immigration increases the size of the market for goods and services by increasing the level of population. With most developed countries, facing a situation of low, no, or negative growth in population, immigration is the only means of augmenting population growth.

"There can be little doubt that immigrant workers have made important contributions to higher rates of economic expansion in the receiving countries" (ILO, 1969: 106). They alleviated labor shortages, enabled the fuller utilization of productive capacity, took up jobs that the nationals did not want, and increased the flexibility of the labor force.

Immigration also, according to studies from Australia, Canada and the US, helps to reduce the pressure on wages in response to demand and thereby moderates inflationary pressures generally. Immigration helps developed countries to establish and maintain contacts with developing countries for international trade and investment activities in the context of globalization.

\section{Exploitation of Natural Resources}

When some countries have insufficient labor supply to exploit and process their natural resources or provide essential services, it becomes essential to import the labor required. The building of trans-Canada railways by imported labor is an instance in point. Oil rich countries of the Middle East - Kuwait, Libya, the UAE and Saudi Arabia - have excess capital, but labor is scarce. Without imported labor it would have been impossible for them to develop. Apart from having a relatively small population, their crude labor force participation rate is in the 18 to 23 range (Birks and Sinclair, 1979: 123). The low participation rate of women in the economy, and the extreme "youthfulness" of the population under discussion, result in the unusually low 'crude' participation rates. Hence 
the monetary rewards for labor are high. Because of labor importation, the expatriate communities in Kuwait, Qatar and UAE outnumber their hosts.

\section{Employment}

A major question that has been raised in the context of international migration is whether immigrants make or take jobs. Studies on this aspect are available from Canada, Australia and the U.S. They maintain that immigrants do not adversely affect total employment in any of these countries (Samuel, 1985; Economic Council of Canada, 1991). Referring to the situation in Australia, Withers says that "if anything, there has been a positive net employment benefit and no wage loss resulting from the Australian immigration program even during the post1974 era of stagflation" (Withers, 1986: 24). At the same time, the migrants themselves have benefited greatly by the move. The maximization of economic and social benefits from migration requires close attention to the composition and volume of intakes and a policy to counter negative attitudes to immigrants and minorities.

The costs to current residents of the territory are: greater labor market competition in some sectors, increased dependence on foreign labor in some occupations, higher demand for public capital stock and social services and social tension with higher number of foreign born in society and the presence of plural cultures.

Singapore has benefited greatly from the inflow of foreign labor. Economic expansion in Singapore has proceeded more rapidly and smoothly than would have been possible with domestic labor supplies alone. At the peak of its economic boom in 1973, Singapore had 100,000 temporary foreign workers, an eighth of its workforce. In addition, professionals were accepted on a longerterm basis. In 1980, Singapore had a labor force of 1.1 million workers and 120,000 were non-citizens, $11 \%$ of the workforce. About a third were permanent residents (Fong, 1982: 556). Government leaders believe that immigrants are able, stable, hardworking and thrifty, and can rouse the competitive spirit of Singaporeans. A similar point of view was expressed by a human resources official of one of big five banks in Canada when it was claimed that immigrants have a higher productivity than native born Canadians (Samuel, 1997).

\section{Social Development}

Another advantage of new immigrants in society is that the individuals in the receiving countries are exposed to new cultures and life styles that add to their quality of life. It also enables the country concerned to develop contacts and connections with many other countries which will pay off in trade deals and negotiations in this age of globalization. However, there could be problems such 
John Samuel and Susan George

as the need to protect the human rights of the new arrivals especially if their ethnicity and race are different from those of the majority of current residents.

\section{Costs of Immigration to North Countries}

\section{Costs of Immigrant Integration}

The costs of international migration to developed countries include the need to foster a socio-political environment in which the fundamental human rights of immigrants in the receiving country are not violated. There are also issues of economic and social integration particularly in the labor market, in areas such as language training, racial discrimination and recognition of qualifications obtained abroad. Special programs may be necessary for the integration of immigrants. Issues of perceived under-utilization of immigrant skills and training in the receiving country is a constant concern.

\section{Destabilization of Economy}

As developing countries become developed, there is a reversal in international migration flows. This could pose a problem for the country that received immigrants in the past if the flow is significant. The business cycle and its rise and fall would also cause such return migration. For instance, during the recession of the 1990s British Columbia experienced an economic boom attributed to the arrival of investor class immigrants.

The receiving country experiences difficulties when the immigrants take their investment out of the country during an economic downturn. This could deepen economic troubles of the country and cause problems of balance of payments and loss in the value of the currency as seems to have happened as a result of the economic problems in some Asian countries.

\section{Illegal Immigration}

Illegal or undocumented migration is part of migration as well. Even if initially it may not have been a problem, after sometime it may snowball especially if the country has a vast land border such as between the US and Mexico. The problem may be less intense in islands such as Australia and Japan. Addressing the US-Mexico illegal flow (involving millions), Weintraub has argued that "even major changes in economic policy are unlikely to double job creation, which would be necessary to make a radical alternation in present emigration processes'" (Appleyard, 1987: 17). He believes that the problem can be solved only in the long term though NAFTA (North American Free Trade Agreement), which was considered to be an effective weapon against illegal migration to the 
US from Mexico. It is very unlikely that higher and higher walls by countries with a 'fortress mentality' can solve the problem of illegal migration.

\section{Issues Common to North and South Countries}

Perceiving development and international immigration within the context of globalization, the issues of private investment, trade, international cooperation, the role of immigrants from the South in the North and sustainable development will be briefly discussed.

\section{Private Investment}

Private investment is extremely significant in the context of globalization. Private investment as a means of influencing future flows of international migrants could be according to either the Japanese or the Western model. The Japanese model of development was to export capital and then bring in the products for home use or export. On the other hand, the Western model relied mostly on importing the factor of production, labor, and to some extent, enterprise. Given the magnitude of the issue of international migration, private investment of foreign capital may have to be increased to accelerate the growth of the economies of Southern countries and to slow down emigration pressures. The emerging prosperity of ASEAN countries (Brunei, Indonesia, Malaysia, the Philippines, Singapore and Thailand) seems to be associated with direct private investment from abroad. Japanese business investment in these countries rose from $\$ 935$ million in 1985 to $\$ 4684$ million in 1989 (Ito, 1993:3). Since the investment has been in the labor intensive manufacturing industry, the job creation effect of this investment has been significant.

The debt crisis of the South has been compounded by an appalling decline in private capital flowing into those countries for investment. Appleyard notes that most of the one trillion dollars gross capital flows in 1987 occurred between industrial countries. "Net transfers to developing countries declined from \$37 billion in 1980 to a negative $\$ 1$ billion 1989..." (Appleyard: 80). Especially with the advent of private enterprise in Eastern Europe, this is likely to be even more marked in the years to come.

\section{Trade}

International trade that enhances access of Southern countries to Northern markets is increasingly being regarded as a principal instrument in globalization that leads to development of the former countries with an inhibiting impact on migration over the long term. According to the U.S. Commission for the Study of International Migration and Co-operative Development, though development 
John Samuel and Susan George

itself may cause emigration initially, "expanded trade between the sending countries and the United States is the single most important long-term remedy..." (1990: xv). Econometric simulations have demonstrated that NAFTA along with "growth enhancing resource transfers from the U.S. to Mexico, can create the conditions for sufficient employment and wage growth in Mexico" (Ojeda, 1993:21).

Aggressive protectionist measures by developed countries are likely to keep immigration pressures strong. "In so far as trade and migration are substitutes, trade policy reform can be used to reduce migration. However, ...trade liberalization and migration may well be complements... at least in the short and medium terms" (Taylor, 1996:24). Undoubtedly, increased imports from the South would cause some disruption to some Northern industries where restructuring would be unavoidable. The opening of the North for the South's products would likely increase structural and frictional unemployment levels in developed countries, especially in selected industries such as textiles. Unfortunately, that seems to be the price to pay. However, the North does have the institutions, social support mechanisms and resources to withstand the adverse consequences of such measures if introduced gradually and strategically.

\section{International Co-operation}

International co-operation is likely to be essential in the years to come as far as North-South relations and migration are concerned. Both sending and receiving regions have a lot to lose if such co-operation is not forthcoming in the economic, social and political fields. Neither the North, nor the South, can face alone the dual challenges of international migration pressure to the North and economic development in the South without the help of the other.

The cold war being over, the energies of the North (now focused on helping Eastern Europe) needs to be concentrated on such co-operation. Arnold and Shah stress the need for such co-operation when they conclude in their analysis of Asian labor migration to the Middle East that "...many problems faced by sending countries are similar in nature. There is, however, no international cooperation or dialogue between the sending countries which may help them jointly maximize the benefits of migration" (Arnold and Shah, 1984: 314.)

\section{Immigrants from the South}

Immigrants from the South now settled in the North, could be used by both groups of countries for the development of the South. The richness of this resource has been overlooked, so far. Apart from sending remittances, as discussed, because of their knowledge of, and contacts with, the receiving and 
sending countries, they are currently in the forefront of developing trade with their former countries. For instance, according to a recent report, "the Hong Kong community in Canada can make it easier to do business in the Chinese interior because of their language and cultural ties" (Hryciuk, 1993). The trade delegations Canada and the US sent to several countries in recent years had a strong representation of immigrants from the respective countries.

In matters of aid, the bilateral, multilateral and NGO agencies depend for policy, program and administration on persons often not familiar with the culture in which the program is supposed to work. As world boundaries are drawn increasingly closer by globalization, there is a need to examine the wisdom of policies that keep out citizens who are born in the South, but became naturalized in the North, from decision-making roles in bilateral, multilateral and NGO agencies.

Private investment is an area where emigrants from the South, now in the North, could assist immensely. Though they themselves may not always have the capital at their command, they do have familiarity with the country concerned, its language, institutions, culture and "chemistry". If these expatriates can guide Northern investors to avoid pitfalls in their former country, such knowledge and guidance would be beneficial.

This also calls for a balanced intake of immigrants by immigration countries from a variety of countries and cultures, on economic, social and humanitarian considerations with the use of a set of criteria that are fair and nondiscriminatory, realizing that immigration is not solely a domestic matter but has wide international implications. All the various aspects of immigrants' qualities and settlement aspects will have to be taken into consideration along with the demographic impacts.

\section{Sustainable Development}

It is apparent that international migration can and does have negative environmental impacts, mainly because of immigrants adopting the life style of their new country. In their former countries, their life style was not as damaging to the environment as in their new country. Thus immigration per se is not the problem though they become "scapegoats for a general failure to adopt sustainable policies of land and other resource use in the destination areas" (Hugo, 1996: 123). Some believe that "the relatively open US immigration policy has resulted in a rate of domestic population growth that threatens both the well-being of American labor and the cherished environmental values" (Abernethy, 1996: 132). 
John Samuel and Susan George

\section{Conclusions}

Development and International migration are closely related in a globalizing world. There are a number of policies that can be developed to promote development while maintaining a mutually (for countries of emigration and immigration) advantageous migration policy. Such initiatives should come from the North which has greater control of world trading systems, resources, influence, and a high stake in the outcome, with the co-operation of the South.

This would require a co-ordinated approach, perhaps under the aegis of the UN, by all countries of the North with full participation of the South. Since all Southern countries are not at the same stage of development, in order to discuss the measures meaningfully, it may be necessary to group Southern countries on the basis of the stage of development with a view to rendering the kind of assistance they can use most productively.

Measures to ease immigration pressures to the North, while promoting economic development in the South through globalization, would encompass easier movement of Southern goods to the North, movement of Northern capital, technology and enterprise to the South and some movement of labor in both directions. The challenge of international migration will remain unabated for a long time to come despite globalization. When the outflows from some regions are under control, others may start to increase. For instance, Western Europe was the region where the outflows dried up first, followed by Southern Europe. Next is likely to be Eastern Europe led by Poland. With NAFTA, Mexico is likely to follow suit.

The North faces a terrible dilemma in trade. There is ambivalence in choosing an appropriate balance between importing the South's labor, the fruits of its labor or the export of capital and technology. This is the Achilles' heel of the North's policy on economic development of the South versus international migration and globalization. The real challenge lies in developing and implementing policies and strategies to stem unwanted migration to the North and to promote economic development in the South in the overall context of globalization.

\section{Acknowledgements:}

We are indebted to Dr. Ranjit Perera for the Canadian International Development Agency's support in the preparation of this paper. 
Globalization, Migration and Development

\section{References:}

Abadan-Unat, Nermin 1977. "Implications of migration on emancipation and pseudo-emancipation of Turkish women," International Migration, XI: 1, Spring.

Abernethy, Virginia 1996 "Environmental and ethical aspects of international migration," International Migration Review, 30:1, Spring.

Appleyard, Reginald 1991. "International Migration: Challenges for the Nineties". Geneva: International Organisation for Migration.

Appleyard, Reginald 1989. "Migration and development: Myths and reality," International Migration Review, xxiii: 3, Fall.

Appleyard, Reginald 1987 "Summary of Main Results" in The Future of Migration. Paris: OECD.

Arnold, Fred and Nasra M. Shah 1984 "Asian migration to the Middle East," International Migration Review, xviii: 2, Summer.

Birks, J.S. and C.A. Sinclair 1979. "The international migration project: An enquiry Into the Middle East labor market." International Migration Review, XIII: 1, Spring.

Bohning, W.R. 1976. "The ILO and contemporary international economic migration," International Migration Review, X:2, Summer.

Bratsberg, Bernt and Dek Terrell 1996"Where do Americans live abroad?" International Migration Review, XXX: 3, Fall.

Castro, Victor Hugo de 1993. "Financial Strategies for Collecting and Employing the Savings of Portuguese Emigrants and Regional Development Prospects". Conference on Migration and International Cooperation: Challenges for OECD Countries, Madrid.

Chin, Ku-Sup, et al. 1996 "Immigrant small business and international economic linkage: A case of the Korean wig business in Los Angeles, 1968-1977," International Migration Review, 30, Summer.

Comay, Yochanan 1971. "Determinants of return migration: Canadian professionals in the US," Southern Economic Journal, 37.

Economic Council of Canada 1991. "New faces in the crowd: Economic and social impacts of immigration," Ottawa. The Economist, April 51993. 
John Samuel and Susan George

Fong, Pang Eng 1982. "Foreign labor and economic development in Singapore," International Migration Review, 16:3, Fall.

Gelbard, Alene Carl Haub and Mary M. Kent 1999. "World population beyond six billion," Population Bulletin, 54:1.

Glytsos, Nicholas 1993. "Measuring the income effects of migrant remittances: A methodical approach applied to Greece," Economic Development and Cultural Change, 42:1, October.

Hryciuk, Dennis 1993. "Canada in line for China trade," Edmonton Journal, April 15, 1993.

Hugo, Graeme 1996. "Environmental concerns and international migration," International Migration Review. 30: 1 Spring.

Iredale, Robyn 2000. "Migration policies for the highly skilled in the AsiaPacific region," International Migration Review, 34: 3 Fall.

Ito, Shoichi 1993. "Japanese Direct Investment in Selected ASEAN countries and Its Impact on Migration". Conference on Migration and International Co-operation: Challenges for OECD Countries, Madrid.

Jones-Correa, Michael 1998. "Different paths: Gender, immigration and political participation," International Migration Review, 32: 2 Summer.

Kappagoda, Nihal 1998. "Private Capital Flows to Developing Countries", Ottawa: Canadian International Development Agency.

Kasmi, Mohamed Tayeb. 1993. "The Construction Industry in Algeria and New Forms of International Co-Operation: Impacts on Employment and Migration". Conference on Migration and International Co-operation: Challenges for OECD Countries, Madrid.

Martin, Philip 1992. "Migration and development," International Migration Review, xxvi: 3.

Martin, Philip and Elizabeth Midgeley 1999. "Immigration to the United States," Population Bulletin, 54:2.

Massey, Douglas S. 1988. "Economic development and international migration in comparative perspective," Population and Development Review, 14:3, September. 
OECD 1993. "Development Challenges, Development Co-operation and Migration". Conference on Migration and International Co-operation: Challenges for OECD Countries, Madrid.

OECD 1991. "Migration: The Demographic Aspects", Paris.

OECD 1987. “The Future of Migration”. Paris: OECD.

Ojeda, Raul Hinojosa. 1993. "North American Free Trade and Migration". Conference on Migration and International Co-operation: Challenges for OECD Countries, Madrid.

Samuel, John 1969a. The Migration of Canadian Born Between Canada and the United States, 1955 to 1968. Ottawa: Manpower and Immigration.

Samuel, John 1969b. "The migration of Canadians to the US": The causes," International Migration, 7, 1,116.

Samuel, John et al. 1997. Visible Minorities and the Public Service of Canada, Canadian Human Rights Commission, Ottawa.

Samuel, John and Beth Woloski 1985. "The labour market experience of Canadian immigrants," International Migration. May.

Shah, Nasra M. 1995. "Structural changes in the receiving country and future labor migration - the case of Kuwait," International Migration Review, XXIX: 4.

Swami, Gurushri 1984. "Population and International Migration". Washington, D.C.: The World Bank.

UNCTAD 1993. "International Trade, Technology and Migration" at the Conference on Migration and International Co-operation: Challenges for OECD Countries. Madrid.

United Nations 1992. "Economic and Social Aspects of Aging in Kerala", India. New York.

U.S. Commission for the Study of International Migration and Co-operative Economic Development. 1990. "Unauthorised Migration: An Economic Development Response". Washington, D.C.

U.S. Immigration and Naturalization Service 1986. "Global Population Trends". Washington, D.C. 
John Samuel and Susan George

Wall Street Journal, The 1993. "G-7 Nations Unveil \$28.4 Billion Plan", April 16, 1993.

Wall Street Journal, The 1993. "Who's Who on Hillary's List", March 26, 1993.

Weintraub, Sidney and Chandler Stalp 1986. "The implications of Growing Economic Interdependence for Future Trends in International Migration", OECD Conference of National Experts on the Future of Migration, May 13-15. Paris: OECD.

Withers, Glen 1986. "The Future of Migration”, OECD, Paris.

Wood, Charles H. and Terry L. McCoy 1985. "Migration remittances and development: A study of Caribbean cane cutters in Florida," International Migration Review, 19:70, Summer.

Wood, Bernard. 1993. "Development Strategies and Migration: Linkages and Possible Lessons". Madrid: Conference organized by OECD, Canada and Spain.

Received February 2001; Revised October 2001 